Supporting information for:

\title{
Synthesis of a Triaza Analogue of Crushed-Fullerene by Intramolecular Palladium-Catalyzed Arylation
}

Berta Gómez-Lor ${ }^{* \dagger}$ and Antonio M. Echavarren ${ }^{*},+$

Instituto de Ciencia de Materiales de Madrid, CSIC, Departamento de Química Orgánica, Universidad Autónoma de Madrid, Cantoblanco, 28049 Madrid and Institute of Chemical Research of Catalonia (ICIQ), 43007 Tarragona, Spain

\section{Experimental Section}

Unless otherwise stated, NMR spectra were recorded at $23^{\circ} \mathrm{C}$. Solvents were purified and dried using standard procedures. Chromatography purifications were carried out using flash grade silica gel with distilled solvents. All reactions were carried out under Ar.

Hexabromotriindene $^{1}$ (10) and 1-bromo-2-bromomethylnaphtalene ${ }^{2}$ were prepared according to known procedures. 4-Nitro-9H-carbazole was prepared by dehydrogenation of 5-nitro-2,3,4,9-tetrahydro- $1 H$-carbazole ${ }^{3} \quad$ with tetrachlorobenzoquinone. ${ }^{4}$

\section{9-(2-Bromophenylmethyl)-4-nitro-9H-carbazole (6).}

A mixture of $9 H$-carbazole (334 mg, $2 \mathrm{mmol}$ ) and $\mathrm{NaH}(104 \mathrm{mg}, 2.6 \mathrm{mmol}, 60 \%$ in mineral oil) in THF $(10 \mathrm{~mL})$ was stirred at room temperature for $15 \mathrm{~min}$. Then, 1bromo-2-bromomethylbenzene $(645 \mathrm{mg}, 2.6 \mathrm{mmol})$ in THF $(2 \mathrm{~mL})$ was added and the mixture was stirred at the same temperature for $16 \mathrm{~h}$. The mixture was diluted with EtOAc and washed with $10 \%$ aqueous $\mathrm{HCl}$ and with saturated aqueous $\mathrm{NaCl}$ solution, dried $\left(\mathrm{Na}_{2} \mathrm{SO}_{4}\right)$, and evaporated. The residue was triturated with hexanes to give 6 as a white solid (598 mg, 89\%): mp 118-120 ${ }^{\circ} \mathrm{C} ;{ }^{1} \mathrm{H}$ NMR (300 MHz, $\left.\mathrm{CDCl}_{3}\right) \delta 8.31$ (d, $J=$ $8.6 \mathrm{~Hz}, 2 \mathrm{H}), 7.78(\mathrm{dd}, J=7.8,1.5 \mathrm{~Hz}, 1 \mathrm{H}), 7.56(\mathrm{dt}, J=8.3,1.2 \mathrm{~Hz}, 2 \mathrm{H}), 7.46-7.38(\mathrm{~m}$, 4H), $7.20(\mathrm{dt}, J=8.1,1.6 \mathrm{~Hz}, 1 \mathrm{H}), 7.06(\mathrm{dt}, J=7.6,1.2 \mathrm{~Hz}, 1 \mathrm{H}), 6.60(\mathrm{~d}, J=7.6 \mathrm{~Hz}$,

1. Robertson, N.; Parsons, S.; MacLean, E. J.; Coxall, R. A.; Mount, A. R. J. Mat. Chem. 2000, 10, $2043-$ 2047.

2. Newman, M. S.; Kosak, S. I. J. Org. Chem. 1949, 14, 375-381.

3. Moslakev, N.; Barbasiewicz, M.; Makosza M. Tetrahedron 2004, 60, 347-358.

4. Barclay, B. M.; Campbell, N. J. Chem. Soc. 1945, 530-533. 
1H) $5.63(\mathrm{~s}, 2 \mathrm{H}) ;{ }^{13} \mathrm{C} \mathrm{NMR}\left(75 \mathrm{MHz}, \mathrm{CDCl}_{3}\right) \delta 140.45,135.76,132.67,128.76,127.70$, $127.23,125.95,123.02,122.07,120.37,119.42,108.74,46.66$.

\section{H-7b-aza-benzo[e]acephenanthrylene (7)}

A mixture of 6 (200 mg, $0.6 \mathrm{mmol}), \mathrm{Pd}(\mathrm{OAc})_{2}(20 \mathrm{mg}, 0.09 \mathrm{mmol}), \mathrm{BnMe} \mathrm{NBr}_{3}(69 \mathrm{mg}$, $0.3 \mathrm{mmol}$ ), and $\mathrm{K}_{2} \mathrm{CO}_{3}(124 \mathrm{mg}, 0.9 \mathrm{mmol})$ in DMF $(8 \mathrm{~mL})$ was stirred at $90^{\circ} \mathrm{C}$ for $2 \mathrm{~h}$. The mixture was cooled to room temperature, diluted with EtOAc and washed with $10 \%$ aqueous $\mathrm{HCl}$ solution, dried $\left(\mathrm{Na}_{2} \mathrm{SO}_{4}\right)$, and evaporated to give 7 as a yellow solid $(153 \mathrm{mg}, 100 \%)$. The spectroscopic data of 7 are identical to those previously reported. ${ }^{5}$

\section{9-(2-Bromophenylmethyl)-4-nitro-9H-carbazole (8)}

A mixture of 4-nitro- $9 H$-carbazole $(106 \mathrm{mg}, 0.5 \mathrm{mmol})$ and $\mathrm{NaH}(26 \mathrm{mg}, 0.65 \mathrm{mmol}$, $60 \%$ in mineral oil) in THF (5 mL) was stirred at room temperature for $15 \mathrm{~min}$. Then, $1-$ bromo-2-bromomethylbenzene (162 $\mathrm{mg}, 0.65 \mathrm{mmol})$ in THF $(1 \mathrm{~mL})$ was added and the mixture was stirred for $16 \mathrm{~h}$. The mixture was diluted with EtOAc and washed with $10 \%$ aqueous $\mathrm{HCl}$ and with saturated aqueous $\mathrm{NaCl}$ solution, dried $\left(\mathrm{Na}_{2} \mathrm{SO}_{4}\right)$ and evaporated. The residue was triturated with hexanes to give 8 as a yellow solid (172 $\mathrm{mg}$, 91\%): mp 122-125 ${ }^{\circ} \mathrm{C} ;{ }^{1} \mathrm{H}$ NMR (300 MHz, $\left.\mathrm{CDCl}_{3}\right) \delta 8.72$ (d, $\left.J=8.5 \mathrm{~Hz}, 1 \mathrm{H}\right), 8.03$ (dd, $J=7.8,1.2 \mathrm{~Hz}, 1 \mathrm{H}), 7.65(\mathrm{dd}, J=8.1,1.2 \mathrm{~Hz}, 1 \mathrm{H}), 7.60-7.45(\mathrm{~m}, 4 \mathrm{H}), 7.38-7.33(\mathrm{~m}$, 2H), $7.13(\mathrm{t}, J=7.4 \mathrm{~Hz}, 1 \mathrm{H}), 7.01(\mathrm{t}, J=7.7 \mathrm{~Hz}, 1 \mathrm{H}), 6.33(\mathrm{~d}, J=7.7 \mathrm{~Hz}, 1 \mathrm{H}) 5.61(\mathrm{~s}$, $2 \mathrm{H}) ;{ }^{13} \mathrm{C} \mathrm{NMR}\left(75 \mathrm{MHz}, \mathrm{CDCl}_{3}\right) \delta 143.82,141.79,141.51,134.68,132.92,129.21$, $128.29,127.84,126.75,125.58,124.91,122.04,120.65,119.22,116.80,115.60$, 114.46, 108.88, 46.82; EI-MS m/z (\%) 380-382 (M+, 66), 254 (34), 169 (100).

\section{4-Nitro-7b-azabenzo $[e]$ acephenanthrylen-8-one (9a) and 3-nitro-7b- azabenzo $[e]$ acephenanthrylen-8-one $(9 \mathrm{~b})$}

A mixture of 8 (76 mg, $0.2 \mathrm{mmol}), \mathrm{Pd}(\mathrm{OAc})_{2}(7 \mathrm{mg}, 0.03 \mathrm{mmol}), \mathrm{BnMe}_{3} \mathrm{NBr}(23 \mathrm{mg}$, $0.1 \mathrm{mmol}$ ), and $\mathrm{K}_{2} \mathrm{CO}_{3}(41 \mathrm{mg}, 0.3 \mathrm{mmol})$ in DMF (4 mL) was stirred at $110^{\circ} \mathrm{C}$ for $2 \mathrm{~h}$. The mixture was cooled to room temperature, diluted with EtOAc and washed with $10 \%$ aqueous $\mathrm{HCl}$ solution, dried $\left(\mathrm{Na}_{2} \mathrm{SO}_{4}\right)$, and evaporated. The residue was dissolved in $\mathrm{CH}_{2} \mathrm{Cl}_{2}$ and $\mathrm{MnO}_{2}$ (excess) was added and the suspension was stirred for $16 \mathrm{~h}$. The resulting mixture was filtered through Celite and the filtrate was evaporated to give a 1.2:1 mixture of $\mathbf{9 a}$ and $\mathbf{9 b}$ as a yellow solid (43 mg, 68\%). Chromatographic

5. Brown, R. F. C.; Choi, N.; Coulston, K. J.; Eastwood, F. W.; Ercole, F.; Horvath, J. M.; Mattinson, M.; Mulder, R. J.; Ooi, H. Ch. Liebigs Ann./Recueil 1997, 1931-1940. 
purification (EtOAc: hexane 1:1) allowed to obtain a partially purified sample of $\mathbf{9 a}(\mathrm{ca}$. 10:1 mixture of $\mathbf{9 a}$ and $\mathbf{9 b}$ ).

9a: ${ }^{1} \mathrm{H}$ NMR $\left(300 \mathrm{MHz}, \mathrm{CDCl}_{3}\right) \delta 9.34(\mathrm{dd}, J=8.9,0.9 \mathrm{~Hz}, 1 \mathrm{H}), 8.72(\mathrm{~d}, J=8.1 \mathrm{~Hz}$, $1 \mathrm{H}), 8.65(\mathrm{dd}, J=8.0,1.2 \mathrm{~Hz}, 1 \mathrm{H}), 8.36-8.27$ (m, 3H), 7.90-7.85 (m, 1H), 7.77-7.64 (m, 3H); EI-MS $m / z(\%) 314\left(\mathrm{M}^{+}, 100\right), 284$ (70).

9b: (only significant signals) ${ }^{1} \mathrm{H}$ NMR $\left(300 \mathrm{MHz}, \mathrm{CDCl}_{3}\right) \delta 8.93(\mathrm{~d}, J=8.1 \mathrm{~Hz}, 1 \mathrm{H})$, $8.24(\mathrm{~d}, J=8.6 \mathrm{~Hz}, 1 \mathrm{H}), 7.60-7.54(\mathrm{~m}, 1 \mathrm{H})$. The EI-MS of the $\mathbf{9 a} / \mathbf{9 b}$ mixture is identical to that of purified 9a.

The structures of $9 \mathbf{a}$ and $\mathbf{9 b}$ were assigned by comparison of the ${ }^{1} \mathrm{H}$ NMR with that of 9H-indolo[3,2,1-de]phenanthridin-9-one (9c) prepared by air oxidation of 7. In addition, in the COSY spectrum of $9 \mathbf{a}$, the lowest-field signal at $\delta 9.34$ correlates with one of the hydrogens at 7.64-7.77 (m. 3H). In the HMBC spectrum of 9a the ${ }^{1} \mathrm{H}$ signal at 8.65 correlates with that at $160 \mathrm{ppm}$ for the carbonyl.

Relevant ${ }^{1} \mathrm{H}$ NMR signals for $\mathbf{9 c}$ and $9 \mathbf{a}$ are shown below.

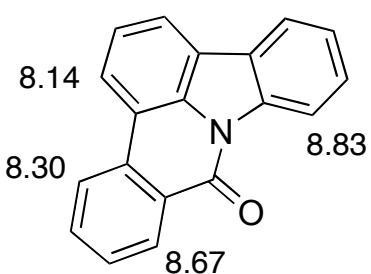

$9 c$

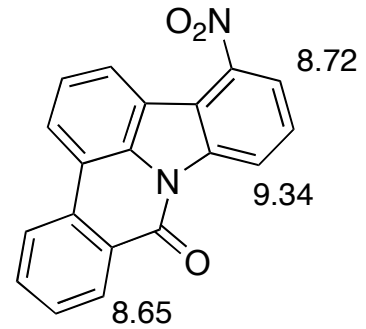

$9 a$

9c: ${ }^{1} \mathrm{H}$ NMR $\left(300 \mathrm{MHz}, \mathrm{CDCl}_{3}\right) \delta 8.83(\mathrm{~d}, 7.8 \mathrm{~Hz}, 1 \mathrm{H}), 8.67(\mathrm{dd}, J=7.9,1.4 \mathrm{~Hz}, 1 \mathrm{H})$, $8.30(\mathrm{~d}, J=8.5 \mathrm{~Hz}, 1 \mathrm{H}), 8.14(\mathrm{~d}, J=8.5 \mathrm{~Hz}, 1 \mathrm{H}), 8.07-8.04(\mathrm{~m}, 2 \mathrm{H}), 7.82(\mathrm{dt}, J=7.3$, 1.6 Hz, $1 \mathrm{H}), 7.68-7.54(\mathrm{~m}, 3 \mathrm{H}), 7.49$ (dt, $J=7.7,1.2 \mathrm{~Hz}, 1 \mathrm{H})$. In the HMBC spectrum the ${ }^{1} \mathrm{H}$ signal at 8.67 correlates with that at 160 ppm for the carbonyl.

\section{0,15-Dihydro-5 $H-5,10,15$-triaza-diindeno[1,2- $a ; 1^{\prime}, 2^{\prime}$-c] fluorene (11)}

A mixture of 10 (406 mg, $0.5 \mathrm{mmol}), \mathrm{Et}_{3} \mathrm{~N}$ (0.55 mL, $\left.4 \mathrm{mmol}\right), \mathrm{HCOOH}(0.15 \mathrm{~mL}, 4$ $\mathrm{mmol})$, and $10 \% \mathrm{Pd} / \mathrm{C}(159 \mathrm{mg}, 0.15 \mathrm{mmol})$ in $\mathrm{MeOH}(40 \mathrm{~mL})$ was heated under refluxing conditions for $30 \mathrm{~min}$. The mixture was filtered through Celite and the filtrate was diluted with $\mathrm{CH}_{2} \mathrm{Cl}_{2}$, washed with aqueous $\mathrm{HCl}(10 \%)$, dried $\left(\mathrm{Na}_{2} \mathrm{SO}_{4}\right)$ and 
evaporated to give 11 as a white solid (164 mg, 95\%): $\mathrm{mp}>300^{\circ} \mathrm{C}$. The spectroscopic data of $\mathbf{1 1}$ are identical to those previously reported. ${ }^{6}$

\section{5,10,15-Tris(1-bromo-2-phenylmethyl)-10,15-dihydro-5H-5,10,15-triaza- diindeno[1,2- $\left.a ; 1^{\prime}, 2^{\prime}-c\right]$ fluorene (12)}

A mixture of 11 (342 mg, $1 \mathrm{mmol})$ and $\mathrm{KOH}(560 \mathrm{mg}, 10 \mathrm{mmol})$ was heated under refluxing conditions in THF $(50 \mathrm{~mL})$. Then, 1-bromo-2-bromomethylbenzene (1) (809 $\mathrm{mg}, 3.25 \mathrm{mmol})$ in THF ( $2 \mathrm{~mL})$ was added and the mixture was heated under refluxing conditions for $3 \mathrm{~h}$. The mixture was cooled to room temperature, diluted with EtOAc and washed with $10 \%$ aqueous $\mathrm{HCl}$ solution and with saturated aqueous $\mathrm{NaCl}$ solution, dried $\left(\mathrm{Na}_{2} \mathrm{SO}_{4}\right)$ and evaporated. The residue was triturated with hexanes to give $\mathbf{1 2}$ as a white solid (790 mg, 93\%): mp 223-225 ${ }^{\circ} \mathrm{C} ;{ }^{1} \mathrm{H}$ NMR (300 MHz, $\left.\mathrm{CDCl}_{3}\right) \delta 7.82-7.80$ $(\mathrm{m}, 3 \mathrm{H}), 7.76(\mathrm{~d}, J=8.1 \mathrm{~Hz}, 3 \mathrm{H}), 7.41-7.38(\mathrm{~m}, 3 \mathrm{H}), 7.28-7.18(\mathrm{~m}, 12 \mathrm{H}), 7.07-7.02(\mathrm{~m}$, $3 \mathrm{H}), 6.02(\mathrm{~s}, 6 \mathrm{H}) ;{ }^{13} \mathrm{C} \mathrm{NMR}\left(75 \mathrm{MHz}, \mathrm{CDCl}_{3}\right) \delta 141.45,139.36,137.10,133.05$, 129.23, 128.76, 128.23, 123.54, 122.93, 122.04, 121.26, 120.67, 110.49, 103.44, 52.23; MALDI-TOF MS $m / z 849\left(\mathrm{M}^{+}\right)$; HRMS (FAB) calcd for $\mathrm{C}_{45} \mathrm{H}_{30}{ }^{79} \mathrm{Br}_{3} \mathrm{~N}_{3}: 848.9990$, found: 848.9995 .

\section{Synthesis of 13}

A mixture of 12 (68 mg, $0.08 \mathrm{mmol}), \mathrm{Pd}(\mathrm{OAc})_{2}(18 \mathrm{mg}, 0.08 \mathrm{mmol}), \mathrm{BnMe}_{3} \mathrm{NBr}(37$ $\mathrm{mg}, 0.16 \mathrm{mmol})$, and $\mathrm{K}_{2} \mathrm{CO}_{3}(110 \mathrm{mg}, 0.8 \mathrm{mmol})$ in DMF $(4 \mathrm{~mL})$ was stirred at $110^{\circ} \mathrm{C}$ for $12 \mathrm{~h}$. The mixture was cooled to room temperature and the solid was filtered off and washed with $\mathrm{CH}_{2} \mathrm{Cl}_{2}$ and acetone. The solid was suspended in $10 \%$ aqueous $\mathrm{NaCN}$ and stirred for $1 \mathrm{~h}$. The solid was filtered off and washed with water and acetone to give 13 as a white powder (35mg, $73 \%): \mathrm{mp}>300^{\circ} \mathrm{C}$. Due to its high insolubility in all solvents, the NMR spectra of 13 could not be obtained. MALDI-TOF MS $m / z 609\left[\mathrm{M}^{+}\right.$]; HRMS (MALDI) calcd for $\mathrm{C}_{45} \mathrm{H}_{27} \mathrm{~N}_{3}$ : 609.2199, found: 609.2190.

\section{5,10,15-Tris(1-bromo-2-naphthylmethyl)-10,15-dihydro-5H-5,10,15-triaza- diindeno[1,2-a; $\left.1^{\prime}, 2^{\prime}-c\right]$ fluorene (14)}

A mixture of 11 (342 mg, $1 \mathrm{mmol})$ and $\mathrm{KOH}(560 \mathrm{mg}, 10 \mathrm{mmol})$ was heated under refluxing conditions in THF $(50 \mathrm{~mL})$. Then, 1-bromo-2-bromomethylnaphtalene (1) (975 $\mathrm{mg}, 3.25 \mathrm{mmol})$ in THF $(5 \mathrm{~mL})$ was added and the mixture was heated under refluxing conditions for $3 \mathrm{~h}$. The mixture was cooled to room temperature, diluted with

6. Bocchi, V.; Palla, G. Tetrahedron Lett. 1986, 42, 5019-5024. 
EtOAc and washed with $10 \%$ aqueous $\mathrm{HCl}$ solution and with saturated aqueous $\mathrm{NaCl}$ solution, dried $\left(\mathrm{Na}_{2} \mathrm{SO}_{4}\right)$ and evaporated. The residue was triturated with hexanes to give 14 (920mg, 92\%) as a white solid: mp: $248-250{ }^{\circ} \mathrm{C} ;{ }^{1} \mathrm{H} \mathrm{NMR}\left(300 \mathrm{MHz}, \mathrm{CDCl}_{3}\right) \delta$ $8.52(\mathrm{~d}, J=8.9 \mathrm{~Hz}, 3 \mathrm{H}), 7.88-7.84(\mathrm{~m}, 6 \mathrm{H}), 7.80-7.71(\mathrm{~m}, 6 \mathrm{H}), 7.63-7.55(\mathrm{~m}, 6 \mathrm{H}), 7.19$ $(\mathrm{d}, J=4.9 \mathrm{~Hz}, 3 \mathrm{H}), 6.98-6.92(\mathrm{~m}, 6 \mathrm{H}), 6.32(\mathrm{~s}, 6 \mathrm{H}) ;{ }^{13} \mathrm{C} \mathrm{NMR}\left(75 \mathrm{MHz}, \mathrm{CDCl}_{3}\right) \delta$ $141.53,139.47,135.29,134.17,132.50,128.65,127.87,126.78,125.39,123.54$, $122.99,122.01,121.29,120.84,110.58,103.52,53.10$ (two carbon signals were not observed); MALDI-TOF MS $m / z 999\left(\mathrm{M}^{+}\right)$; HRMS (FAB) calcd for $\mathrm{C}_{57} \mathrm{H}_{36}{ }^{79} \mathrm{Br}_{3} \mathrm{~N}_{3}$ : 999.0459, found: 999.0459 .

\section{Synthesis of 3}

A mixture of $14(50 \mathrm{mg}, 0.05 \mathrm{mmol}), \mathrm{Pd}(\mathrm{OAc})_{2}(11 \mathrm{mg}, 0.05 \mathrm{mmol}), \mathrm{BnMe}_{3} \mathrm{NBr}(23$ $\mathrm{mg}, 0.1 \mathrm{mmol})$, and $\mathrm{K}_{2} \mathrm{CO}_{3}(69 \mathrm{mg}, 0.5 \mathrm{mmol})$ in DMF $(3 \mathrm{~mL})$ was stirred at $110^{\circ} \mathrm{C}$ for $12 \mathrm{~h}$. The mixture was cooled to $23^{\circ} \mathrm{C}$ and the solid was filtered off and washed with $\mathrm{CH}_{2} \mathrm{Cl}_{2}$ and acetone. The solid was suspended in $10 \%$ aqueous $\mathrm{NaCN}$ and stirred for 1 h. The solid was filtered off and washed with water and acetone to give $\mathbf{3}$ as a yellow powder (23 mg, 61\%): $\mathrm{mp}>300^{\circ} \mathrm{C} ;{ }^{1} \mathrm{H}$ NMR (1,1,2,2-tetrachloroethane- $d_{2}, 100{ }^{\circ} \mathrm{C}, 300$ MHz) $\delta 8.99(\mathrm{~d}, J=8.8 \mathrm{~Hz}, 3 \mathrm{H}), 8.33(\mathrm{~d}, J=7.6 \mathrm{~Hz}, 3 \mathrm{H}), 8.24$ (d, $J=7.6 \mathrm{~Hz}, 3 \mathrm{H}), 7.95$ $(\mathrm{d}, J=8.0 \mathrm{~Hz}, 3 \mathrm{H}), 7.91(\mathrm{~d}, J=8.3 \mathrm{~Hz}, 3 \mathrm{H}), 7.65-7.51(\mathrm{~m}, 12 \mathrm{H}), 5.89(\mathrm{~s}, 6 \mathrm{H})$; MALDITOF MS m/z $758\left[\mathrm{M}^{+}-\mathrm{H}\right]$; HRMS (FAB) calcd for. $\mathrm{C}_{57} \mathrm{H}_{33} \mathrm{~N}_{3}$ 759.2674, found 759.2671 .

\section{5,10,15-Tribenzyl-2,3,7,8,12,13-hexabromo-10,15-dihydro-5H-5,10,15-triaza- diindeno[1,2- $\left.a ; 1^{\prime}, 2^{\prime}-c\right]$ fluorene (15)}

A mixture of 10 (406 mg, $0.5 \mathrm{mmol})$ and $\mathrm{KOH}(280 \mathrm{mg}, 5 \mathrm{mmol})$ was heated under refluxing conditions in THF $(50 \mathrm{~mL})$. Then, benzyl bromide $(277 \mathrm{mg}, 1.62 \mathrm{mmol})$ in THF ( $2 \mathrm{~mL}$ ) was added and the mixture was heated under refluxing conditions for $3 \mathrm{~h}$. The mixture was cooled to room temperature, diluted with EtOAc and washed with $10 \%$ aqueous $\mathrm{HCl}$ solution and with saturated aqueous $\mathrm{NaCl}$ solution, dried $\left(\mathrm{Na}_{2} \mathrm{SO}_{4}\right)$ and evaporated. The residue was triturated with hexanes to give $\mathbf{1 5}$ as a white solid (493 mg, 91\%): $\mathrm{mp}>300^{\circ} \mathrm{C} ;{ }^{1} \mathrm{H}$ NMR $\left(300 \mathrm{MHz}, \mathrm{CDCl}_{3}\right) \delta 8.13(\mathrm{~s}, 3 \mathrm{H}), 7.51(\mathrm{~s}, 3 \mathrm{H}), 7.49-$ $7.42\left(\mathrm{~m}, J=7.8 \mathrm{~Hz}, 15 \mathrm{H}\right.$ ), 5.94 (s, 6H); MALDI-TOF MS $m / z 1081\left[\mathrm{M}^{+}\right]$.

\section{5,10,15-Tribenzyl-2,3,7,8,12,13-hexaphenyl-10,15-dihydro-5H-5,10,15-triaza- diindeno[1,2- $\left.a ; 1^{\prime}, 2^{\prime}-c\right]$ fluorene (16)}


A mixture of 15 (54 mg, $0.05 \mathrm{mmol}), \mathrm{Pd}\left(\mathrm{PPh}_{3}\right)_{4}(35 \mathrm{mg}, 0.03 \mathrm{mmol})$, aqueous $2 \mathrm{M}$ $\mathrm{K}_{2} \mathrm{CO}_{3}(300 \mu \mathrm{L}, 0.6 \mathrm{mmol})$, and phenylboronic acid (54 $\left.\mathrm{mg}, 0.45 \mathrm{mmol}\right)$ in toluene $(2.5$ $\mathrm{mL})$ and $\mathrm{EtOH}(0.75 \mathrm{~mL})$ was heated under refluxing conditions for $16 \mathrm{~h}$. The reaction mixture was cooled to room temperature and diluted with EtOAc and washed 10\% aqueous $\mathrm{HCl}$ solution and with saturated aqueous $\mathrm{NaCl}$ solution, dried $\left(\mathrm{Na}_{2} \mathrm{SO}_{4}\right)$ and evaporated. The residue was triturated with hexanes to give $\mathbf{1 6}$ as a white solid (40 mg, $74 \%): \mathrm{mp}>300^{\circ} \mathrm{C} ;{ }^{1} \mathrm{H}$ NMR $\left(1,1,2,2\right.$-tetrachloroethane- $\left.d_{2}, 130{ }^{\circ} \mathrm{C}, 300 \mathrm{MHz}\right) \delta 8.12(\mathrm{~s}$, 3H), $7.40(\mathrm{~d}, J=7.8 \mathrm{~Hz}, 6 \mathrm{H}), 7.30(\mathrm{~s}, 3 \mathrm{H}), 7.26-7.23(\mathrm{~m}, 9 \mathrm{H}), 7.08-7.03(\mathrm{~m}, 18 \mathrm{H})$, 7.01-6.98 (m, 6H), $6.80(\mathrm{~d}, J=7.2 \mathrm{~Hz}, 6 \mathrm{H}), 6.16(\mathrm{~s}, 6 \mathrm{H}) ;{ }^{13} \mathrm{C} \mathrm{NMR}\left(\mathrm{CDCl}_{3}, 75 \mathrm{MHz}\right) \delta$ $142.03,141.64,140.44,139.86,138.05,136.01,133.22,130.24,129.93,129.35$, $127.81,127.23,126.22,126.05,125.33,124.58,121.62,111.41,102.27,49.81$; MALDI-TOF MS m/z $1071\left[\mathrm{M}^{+}+\mathrm{H}\right]$. HRMS (FAB) calcd for. $\mathrm{C}_{81} \mathrm{H}_{57} \mathrm{~N}_{3}$ 1071.4552, found 1071.4578 . 
3: ${ }^{1} \mathrm{H}$ NMR $\left(1,1,2,2\right.$-tetrachloroethane- $\left.d_{2}, 100{ }^{\circ} \mathrm{C}, 300 \mathrm{MHz}\right)$.

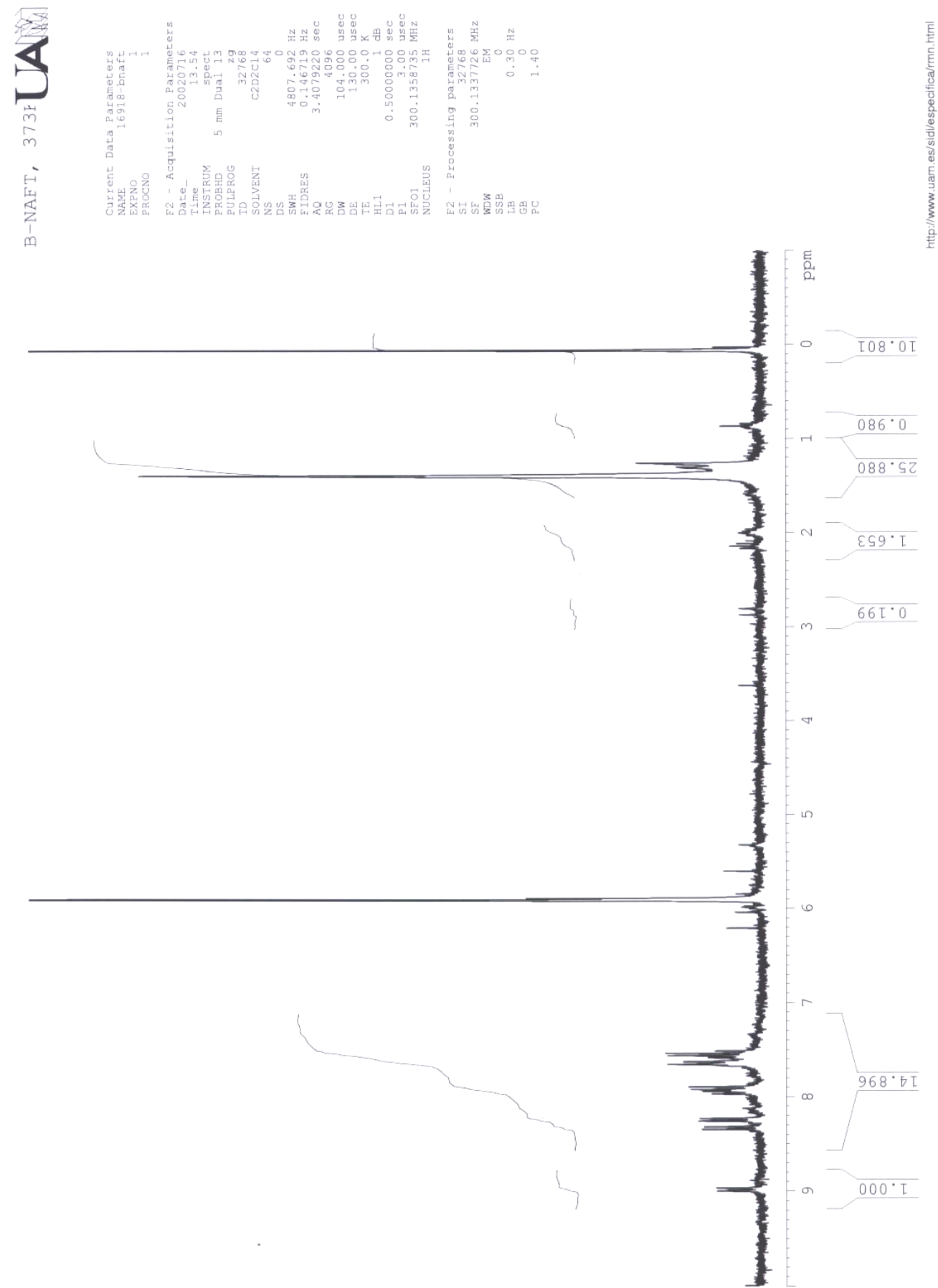


3: MALDI-TOF spectrum

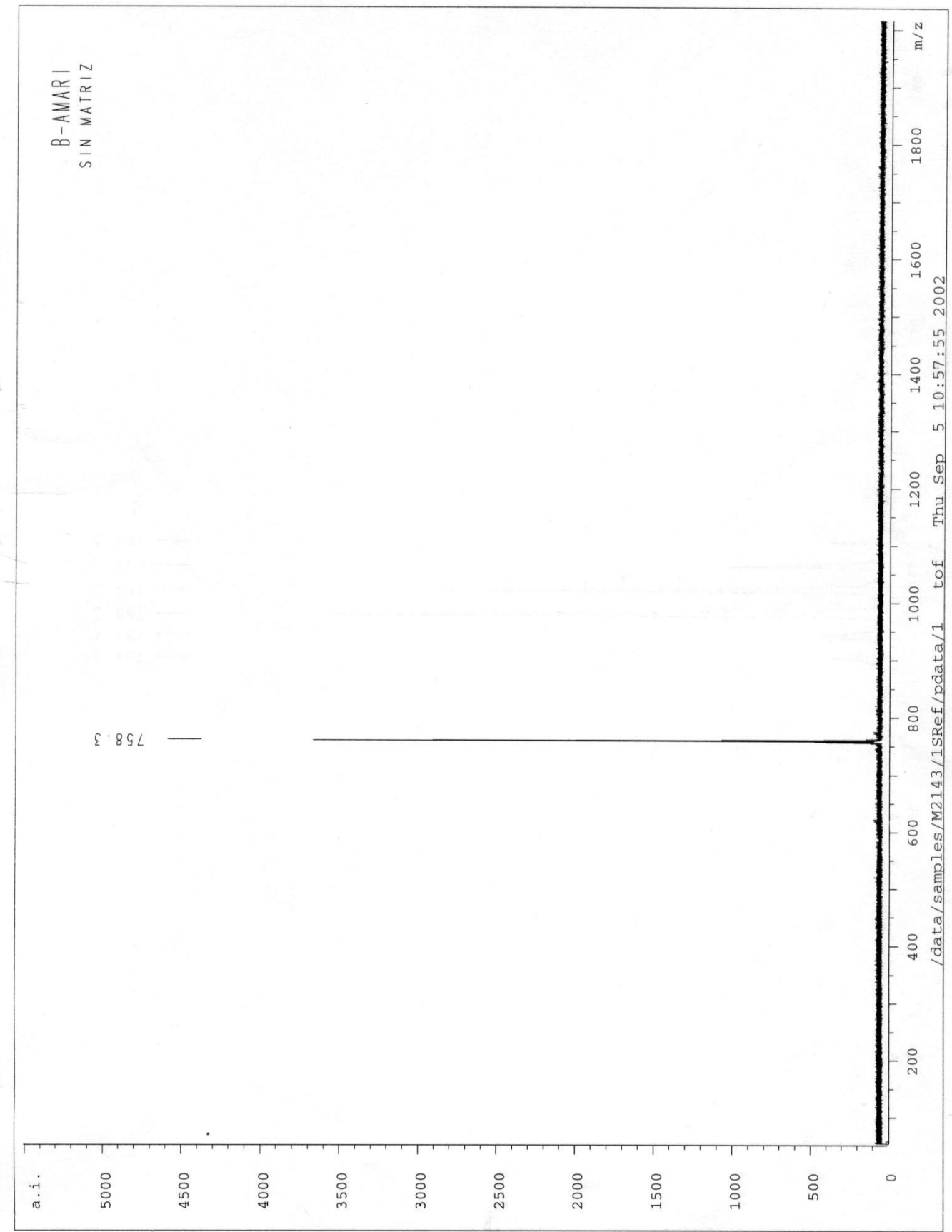


9-(2-Bromophenylmethyl)-4-nitro-9H-carbazole (6): ${ }^{1} \mathrm{H}$ NMR $\left(300 \mathrm{MHz}, \mathrm{CDCl}_{3}\right)$

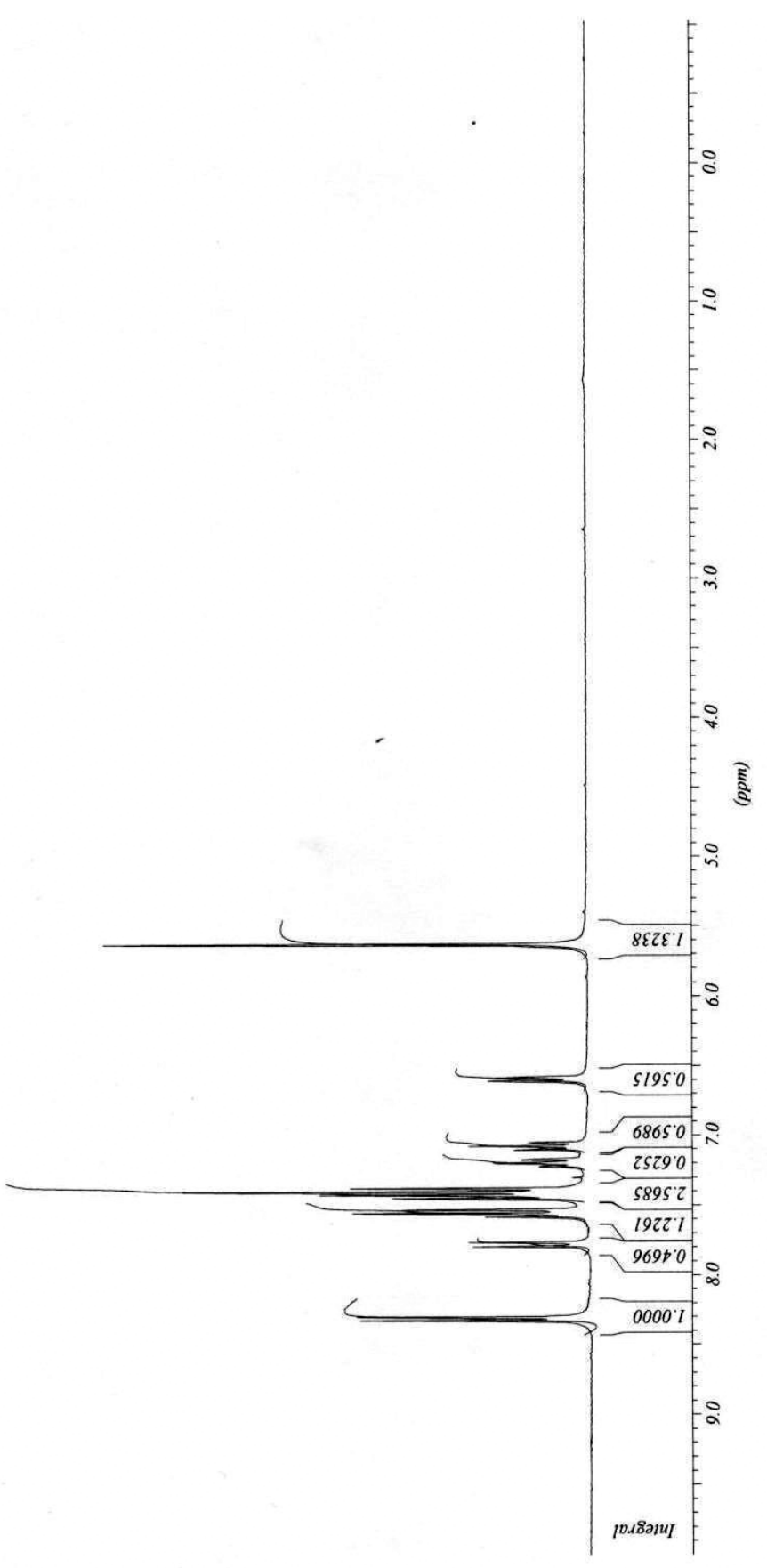


9-(2-Bromophenylmethyl)-4-nitro-9H-carbazole: ${ }^{13} \mathrm{C} \mathrm{NMR}\left(75 \mathrm{MHz}, \mathrm{CDCl}_{3}\right)$

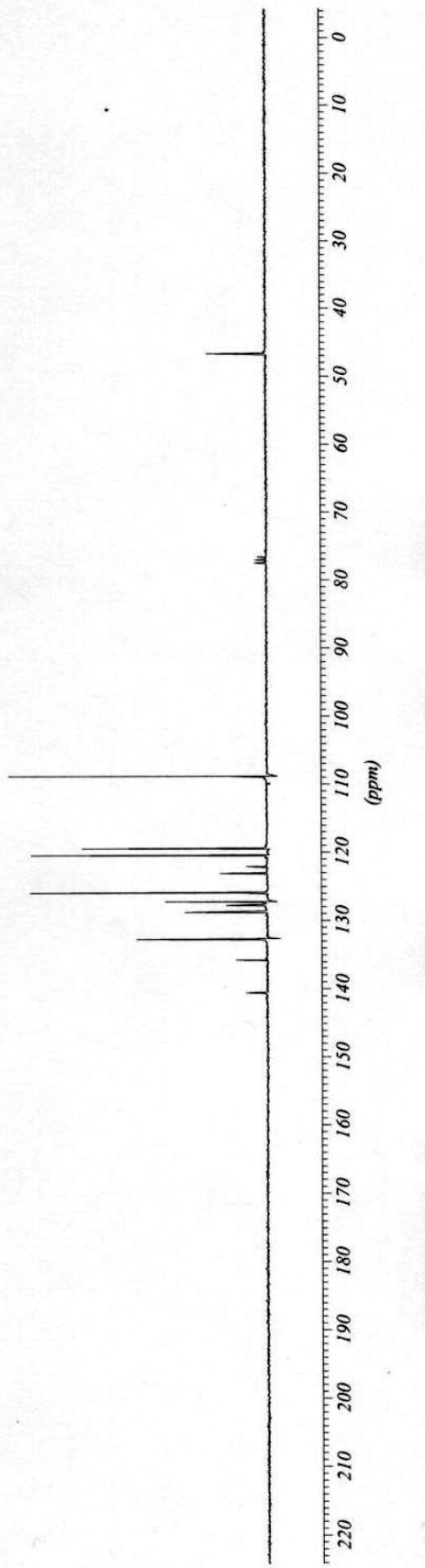


9-(2-Bromophenylmethyl)-4-nitro-9H-carbazole (8): ${ }^{1} \mathrm{H} \mathrm{NMR}\left(300 \mathrm{MHz}, \mathrm{CDCl}_{3}\right)$

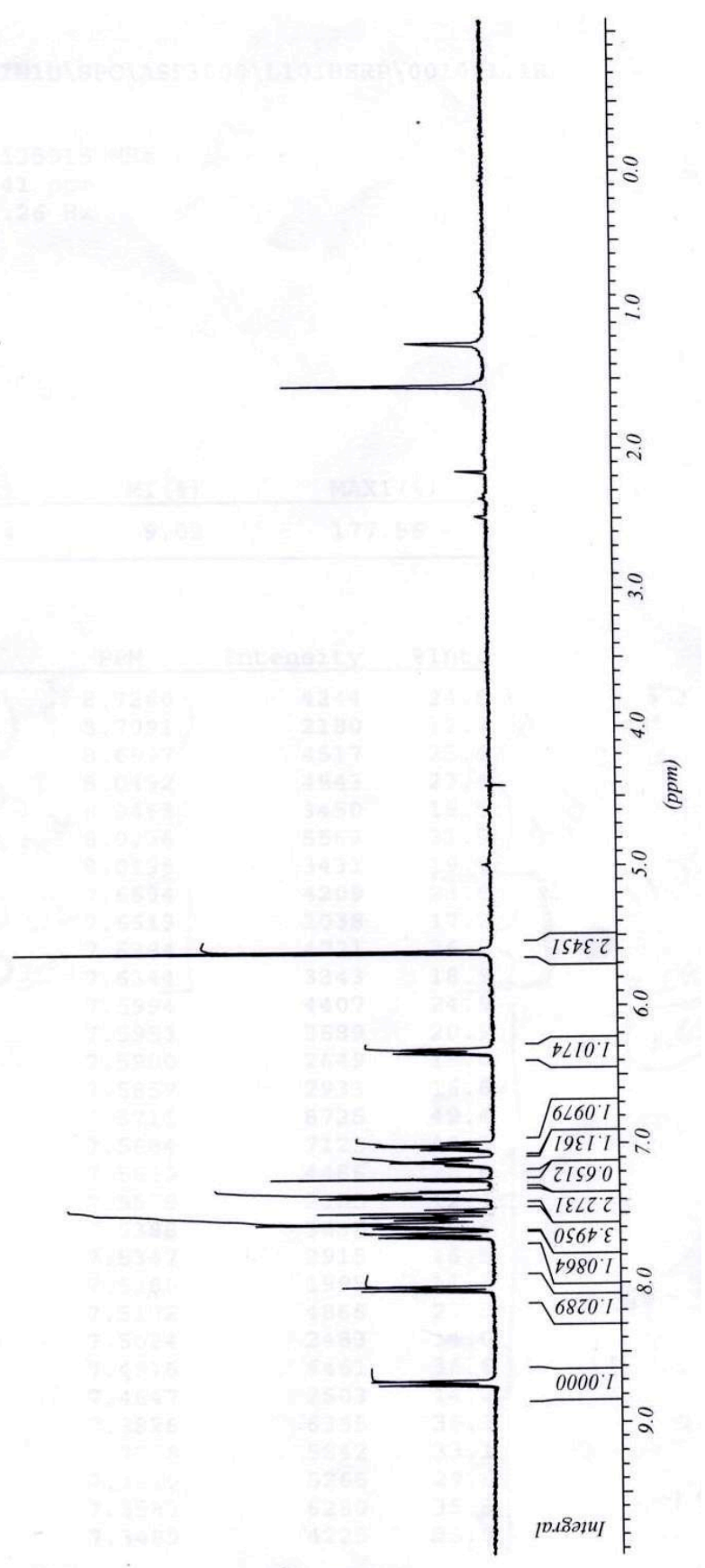

1 
9-(2-Bromophenylmethyl)-4-nitro-9H-carbazole (8): ${ }^{13} \mathrm{C} \mathrm{NMR}\left(75 \mathrm{MHz}, \mathrm{CDCl}_{3}\right)$

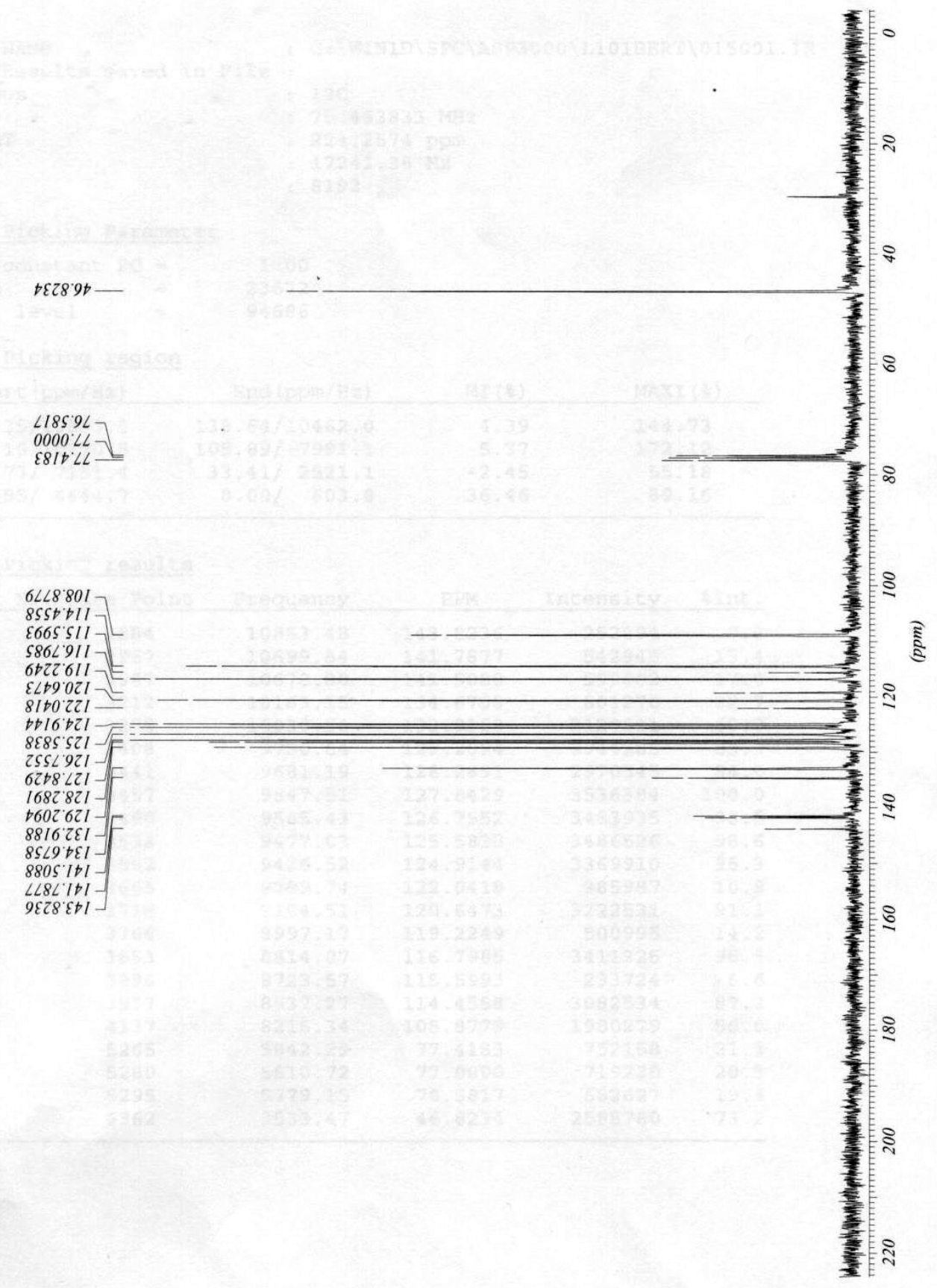


-Nitro-7b-azabenzo[e]acephenanthrylen-8-one (9a) and 3-nitro-7bazabenzo[e] acephenanthrylen-8-one (9b): ${ }^{1} \mathrm{H} \mathrm{NMR}\left(300 \mathrm{MHz}, \mathrm{CDCl}_{3}\right)$

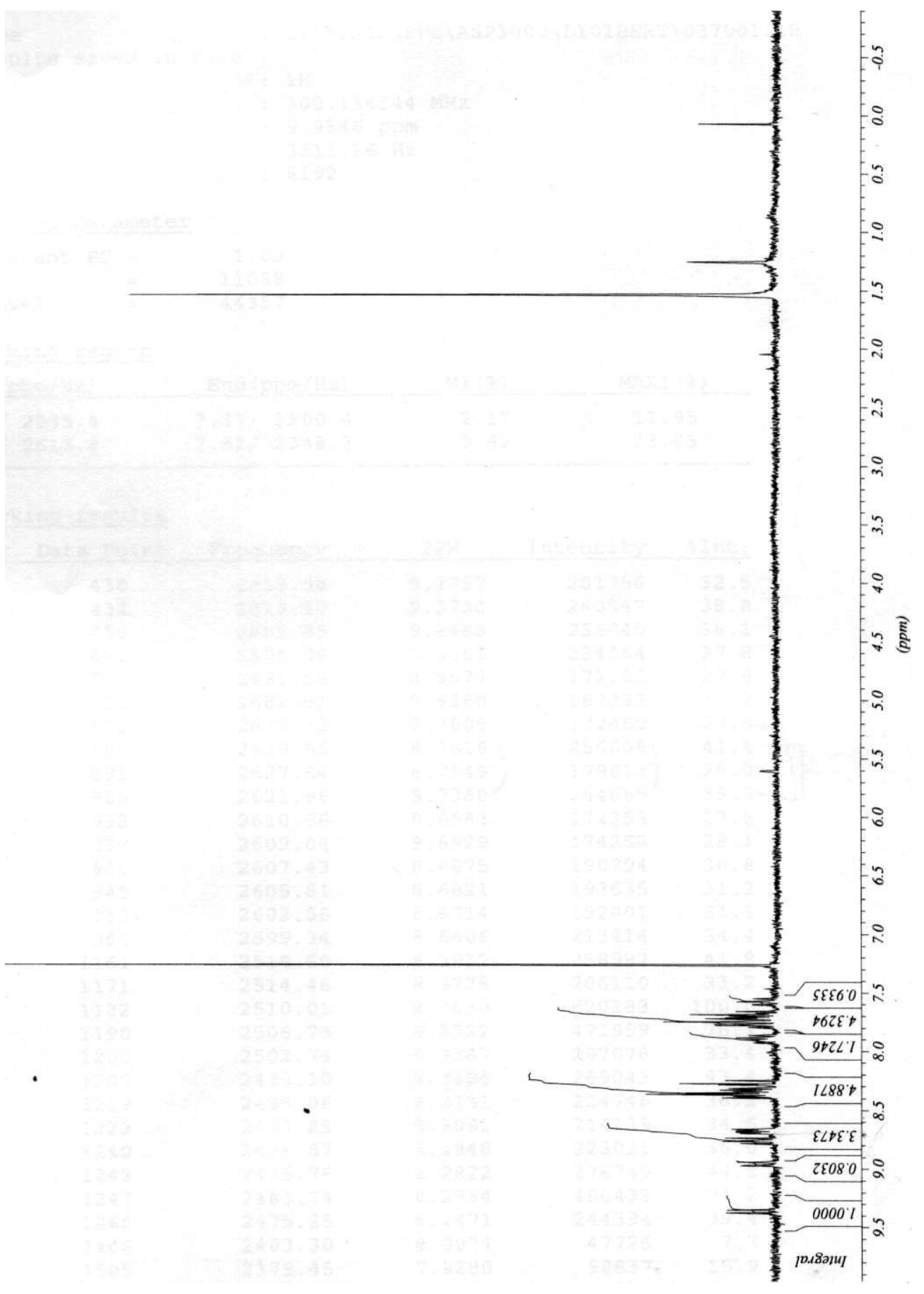


4-Nitro-7b-azabenzo[e] acephenanthrylen-8-one (9a): ${ }^{1} \mathrm{H} \mathrm{NMR}\left(300 \mathrm{MHz}, \mathrm{CDCl}_{3}\right)$

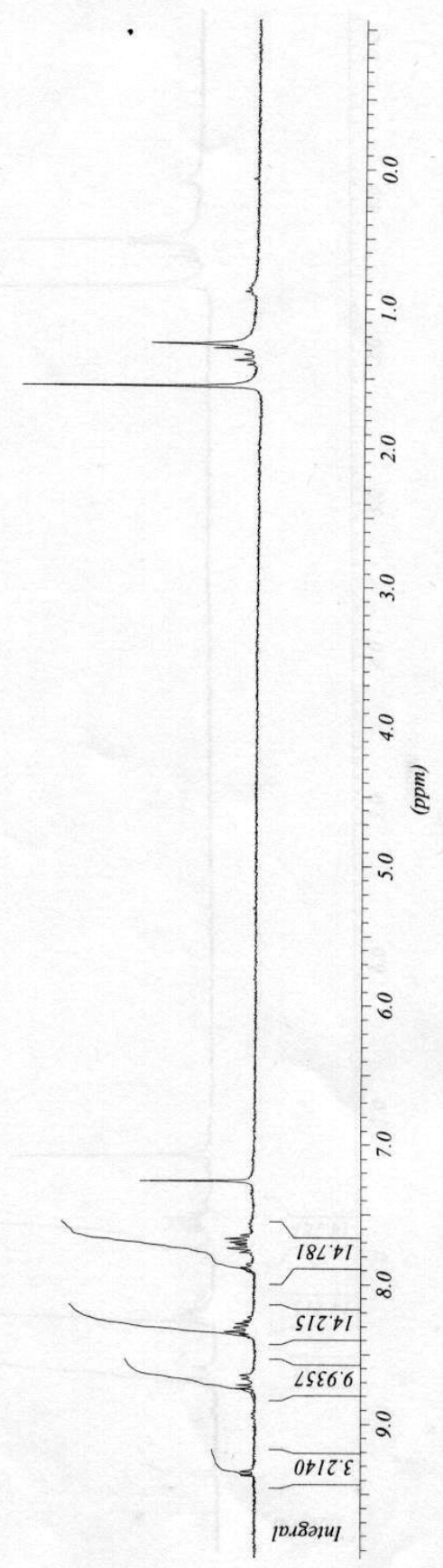


5,10,15-Tris(1-bromo-2-phenylmethyl)-10,15-dihydro-5H-5,10,15-triazadiindeno[1,2-a;1',2'-c]fluorene (12): ${ }^{1} \mathrm{H} \mathrm{NMR}\left(300 \mathrm{MHz}, \mathrm{CDCl}_{3}\right)$

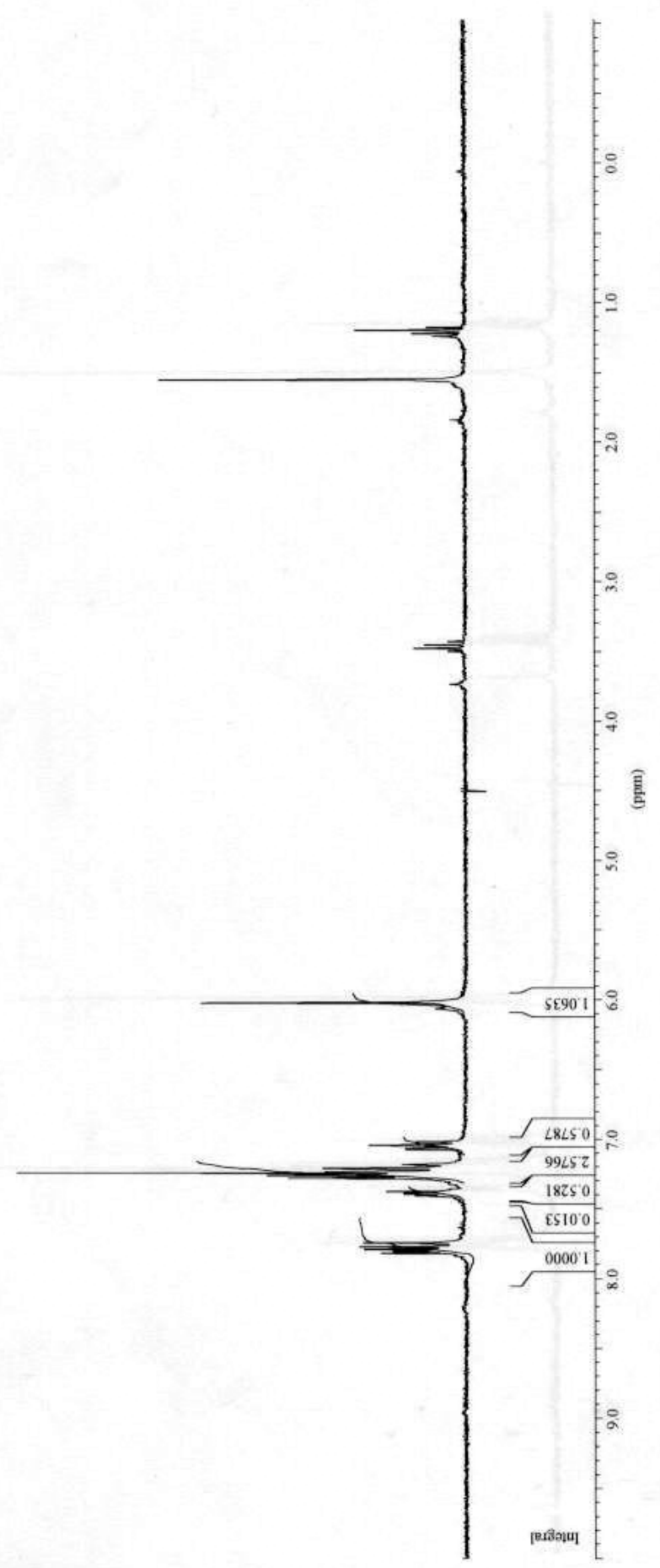


5,10,15-Tris(1-bromo-2-phenylmethyl)-10,15-dihydro-5H-5,10,15-triazadiindeno[1,2-a;1',2'-c]fluorene (12): ${ }^{13} \mathrm{C} \mathrm{NMR}\left(75 \mathrm{MHz}, \mathrm{CDCl}_{3}\right)$

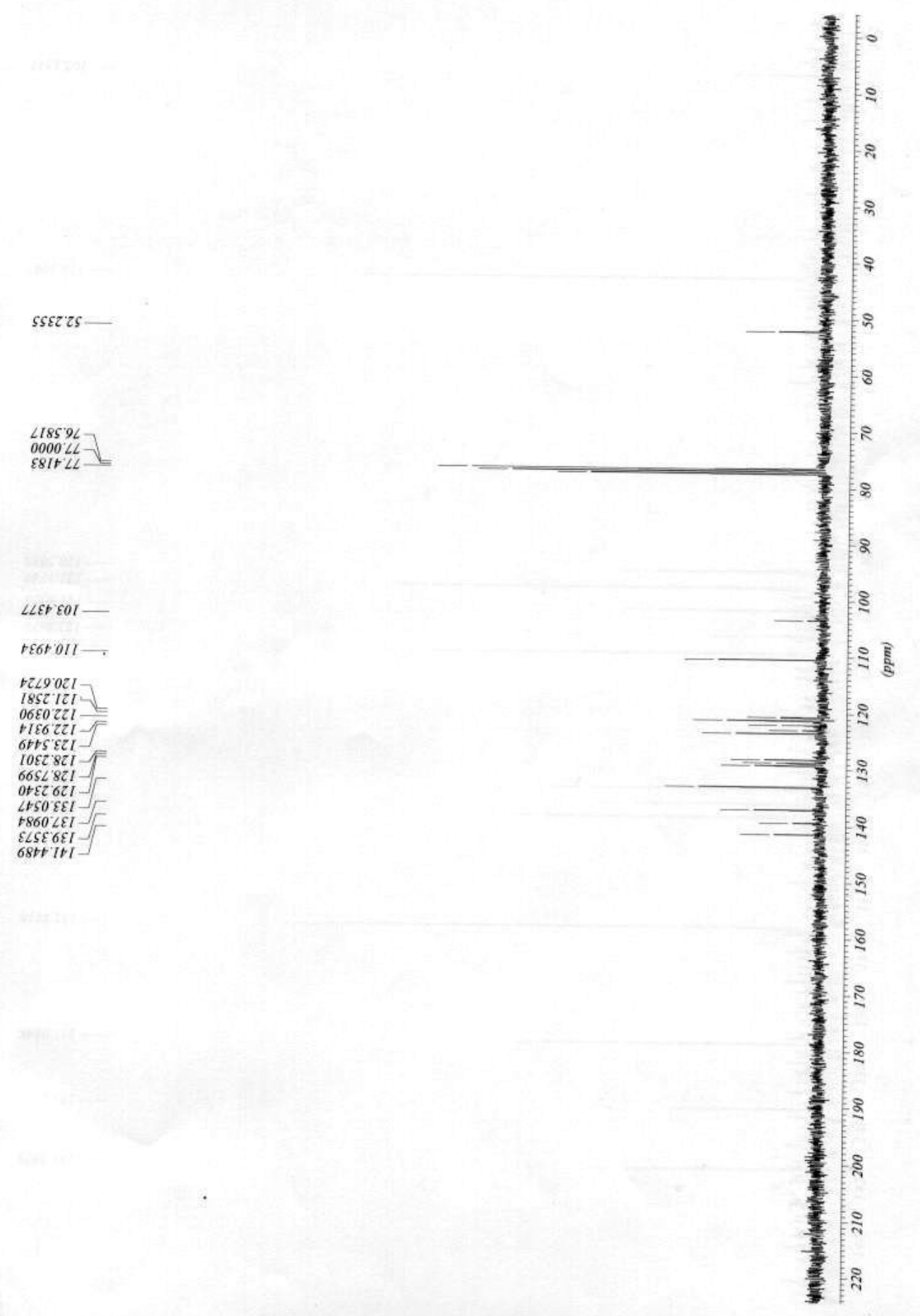


13: MALDI-TOF spectrum

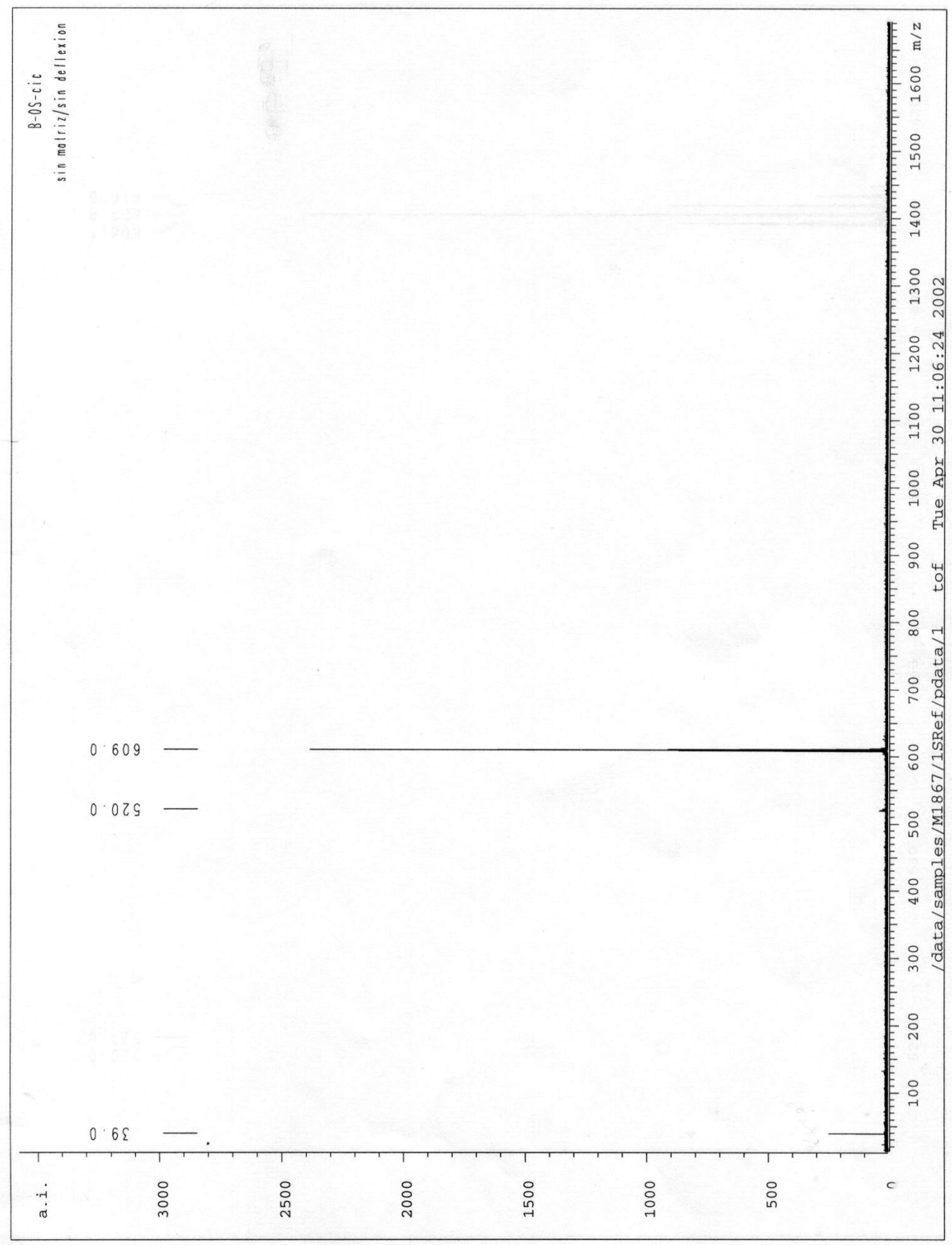


5,10,15-Tris(1-bromo-2-naphthylmethyl)-10,15-dihydro-5H-5,10,15-triazadiindeno[1,2-a;1',2'-c]fluorene (14): ${ }^{1} \mathrm{H} \mathrm{NMR}\left(300 \mathrm{MHz}, \mathrm{CDCl}_{3}\right)$

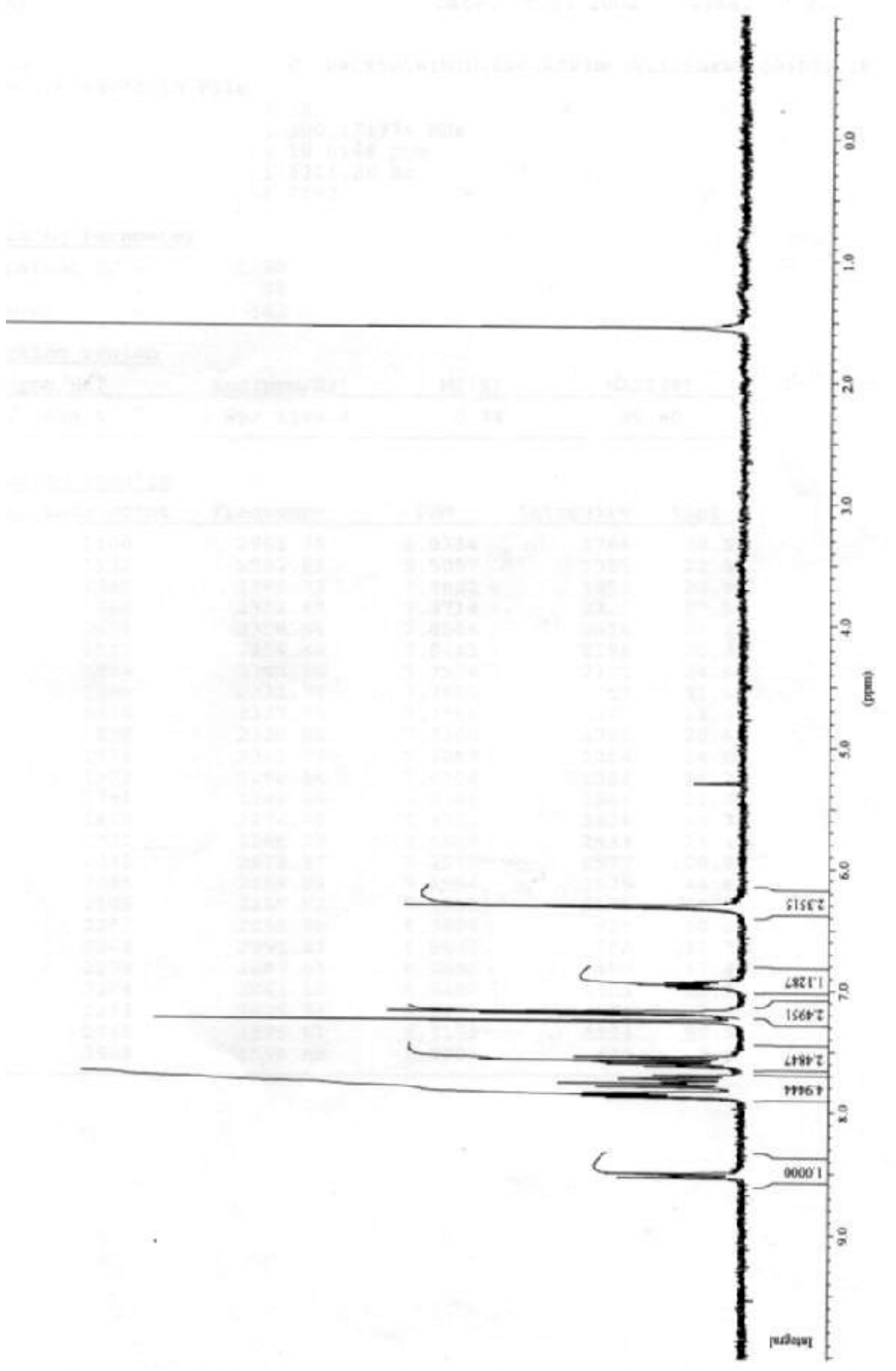


5,10,15-Tris(1-bromo-2-naphthylmethyl)-10,15-dihydro-5H-5,10,15-triazadiindeno[1,2-a;1',2'-c]fluorene (14): ${ }^{13} \mathrm{C}$ NMR (75 MHz, $\mathrm{CDCl}_{3}$ )
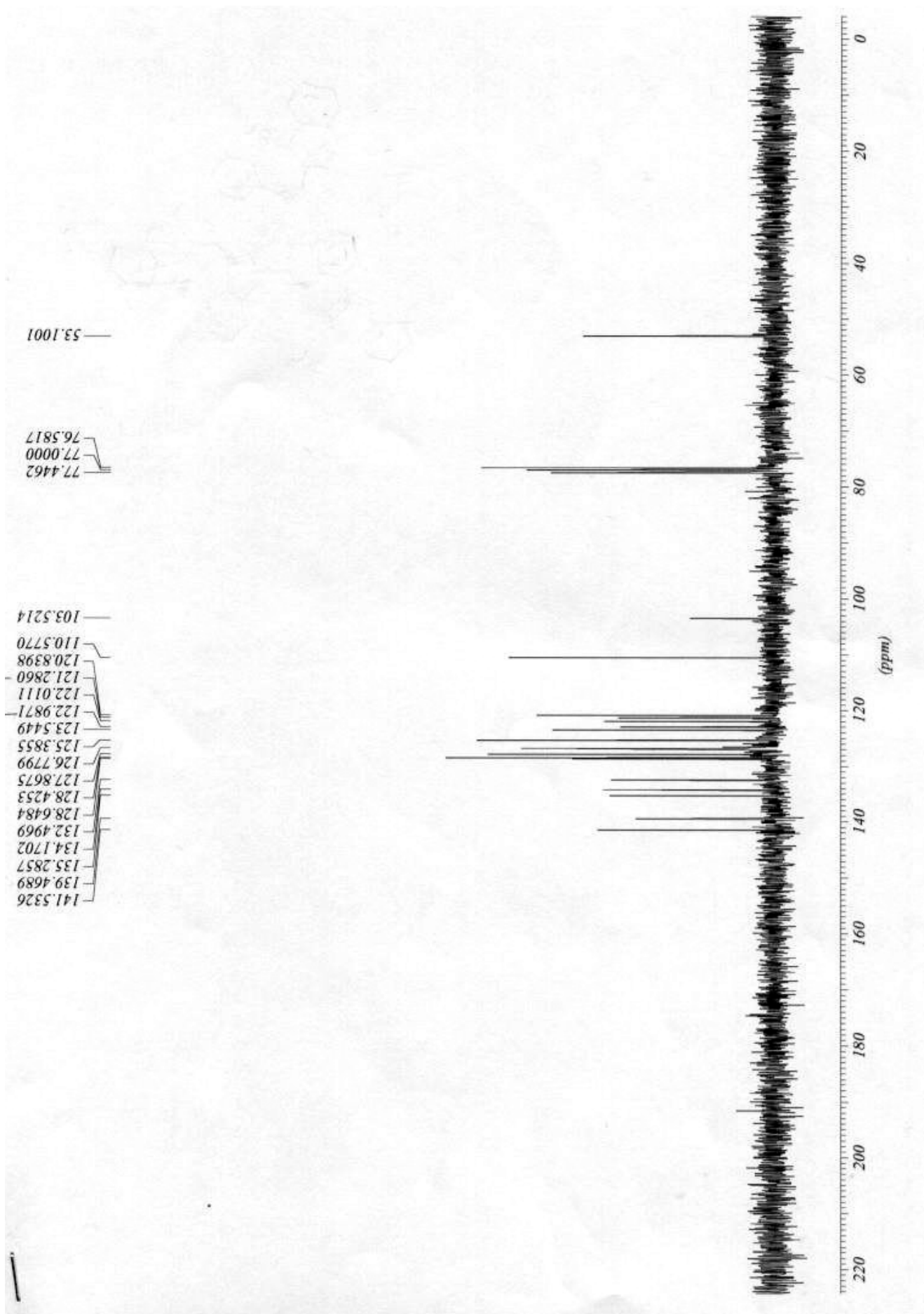
5,10,15-Tribenzyl-2,3,7,8,12,13-hexabromo-10,15-dihydro-5H-5,10,15-triazadiindeno[1,2-a;1',2'-c]fluorene (15): ${ }^{1} \mathrm{H} \mathrm{NMR}\left(300 \mathrm{MHz}, \mathrm{CDCl}_{3}\right)$

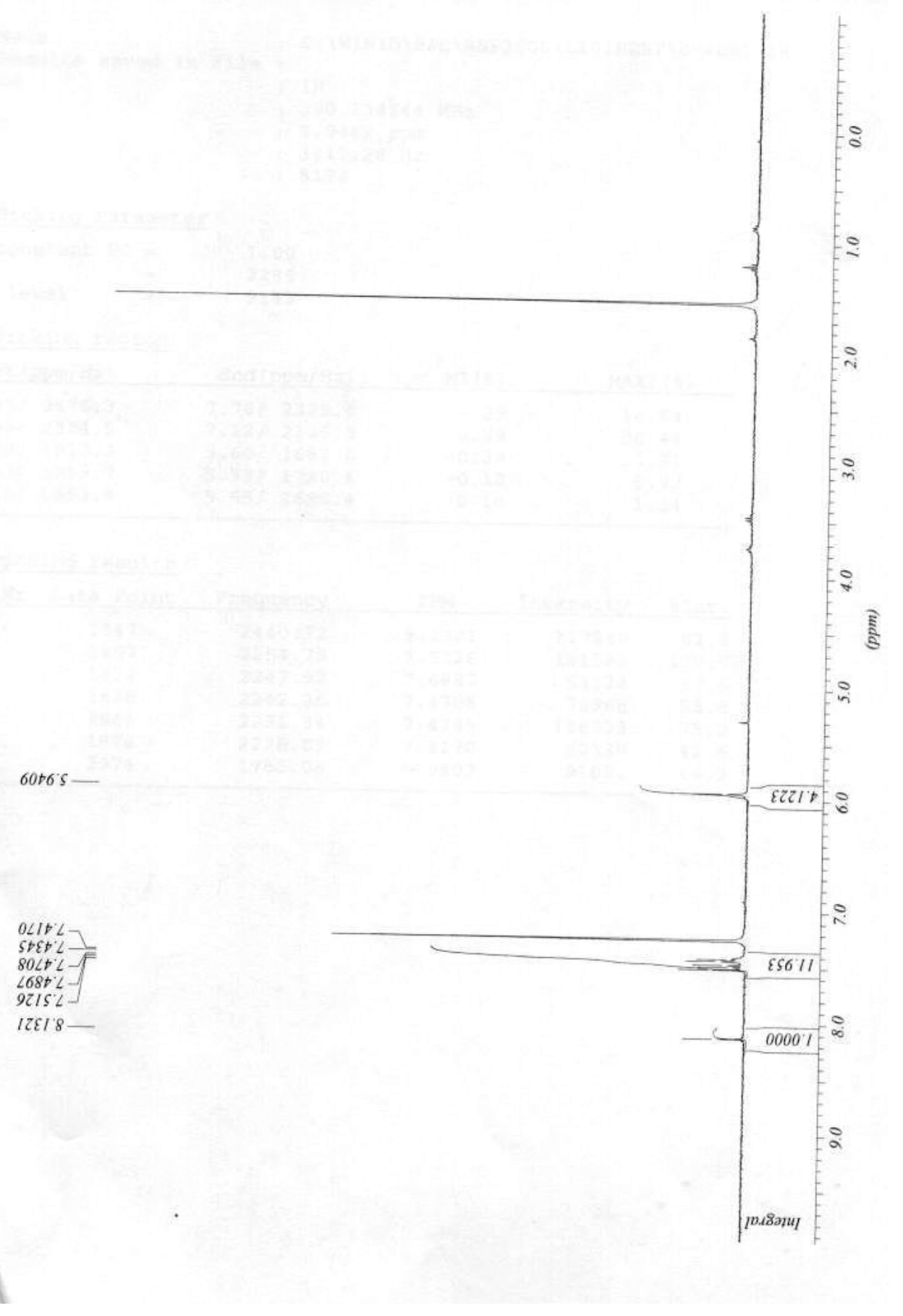


5,10,15-Tribenzyl-2,3,7,8,12,13-hexaphenyl-10,15-dihydro-5H-5,10,15-triazadiindeno[1,2-a;1',2'-c]fluorene (16): ${ }^{1} \mathrm{H}$ NMR $\left(1,1,2,2\right.$-tetrachloroethane- $d_{2}, 130{ }^{\circ} \mathrm{C}$, $300 \mathrm{MHz})$

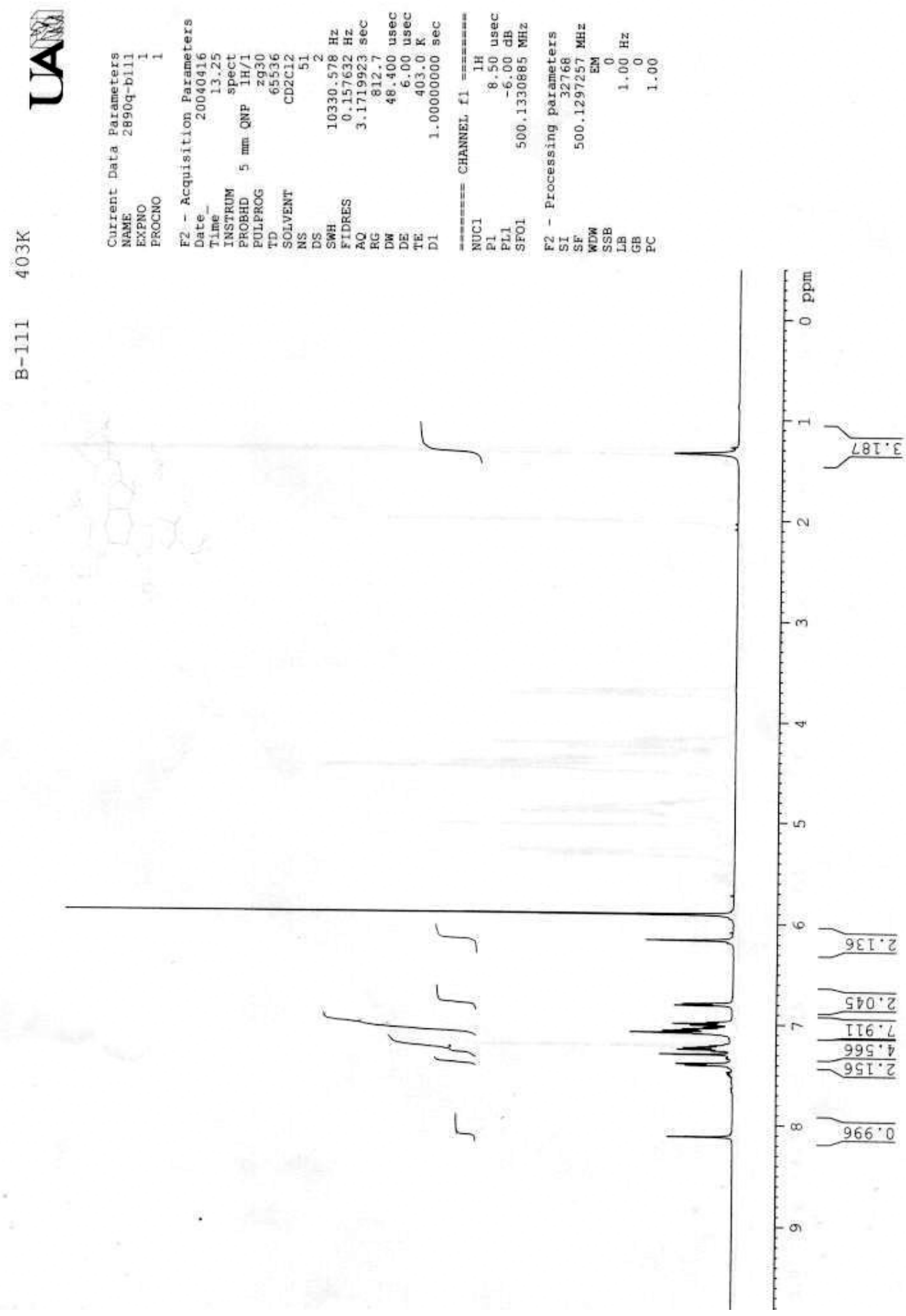


5,10,15-Tribenzyl-2,3,7,8,12,13-hexaphenyl-10,15-dihydro-5H-5,10,15-triazadiindeno[1,2-a;1',2'-c]fluorene (16): ${ }^{13} \mathrm{C} \mathrm{NMR}\left(\mathrm{CDCl}_{3}, 75 \mathrm{MHz}\right)$

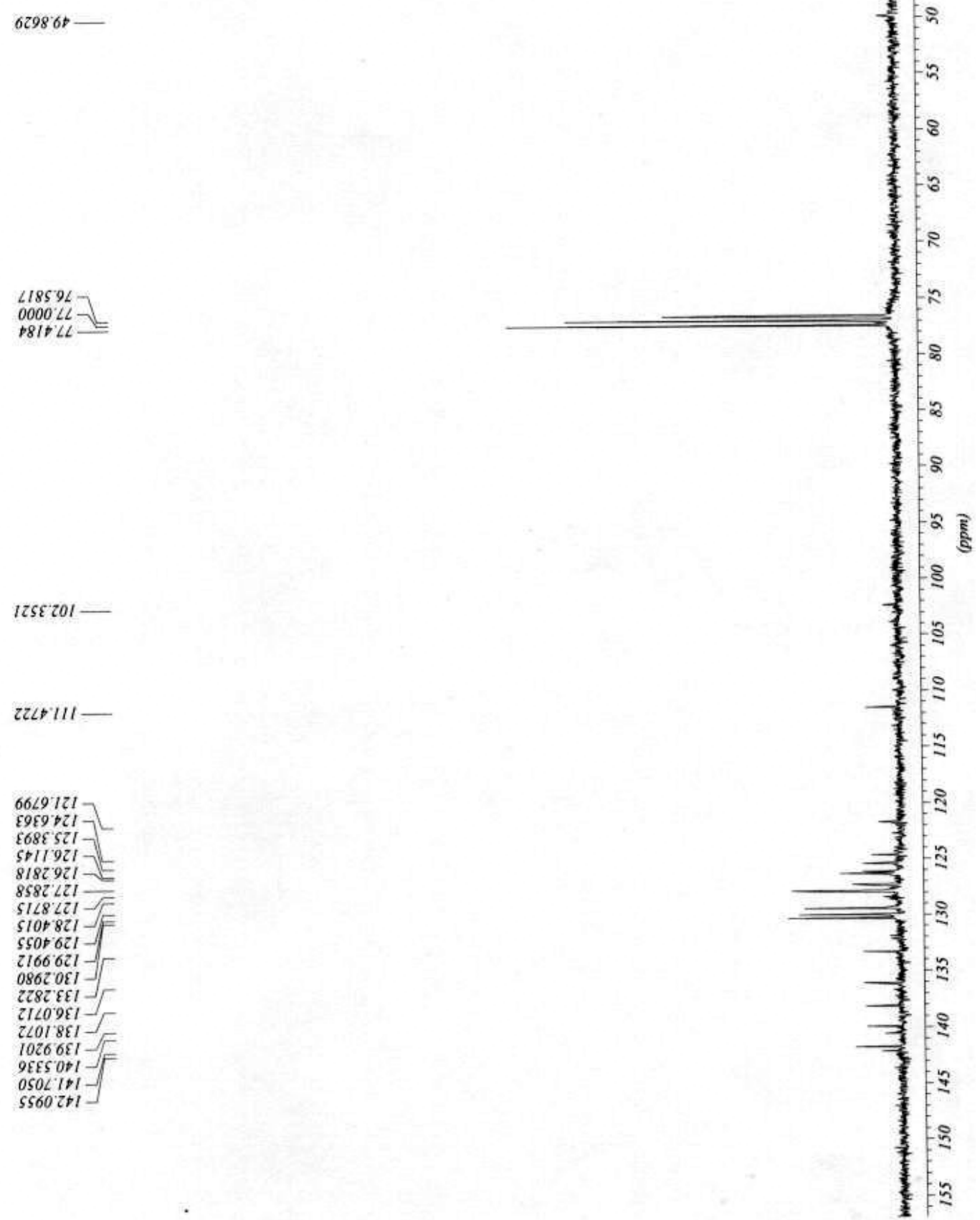

